\title{
The Effect of Macroeconomic Variables on Accounting Profit Transparency (Case Study: Basic Metals Industry Companies Listed on Tehran Stock Exchange)
}

\author{
Reza Sarvari ${ }^{1}$, Ehsan khansalar ${ }^{2} \&$ Mohammad Delkhosh ${ }^{1}$ \\ ${ }^{1}$ Department of Accounting, Qaenat Branch, Islamic Azad University, Qaenat, Iran \\ ${ }^{2}$ Departement of Accounting, Finance and Informatics, Kingston University, London, UK \\ Correspondence: Reza Sarvari, Department of Accounting, Qaenat Branch, Islamic Azad University, Qaenat, \\ Iran. E-mail: rezasarvari2014@yahoo.com
}

Received: March 12, 2016

Accepted: May 3, 2016

Online Published: April 25, 2016

doi:10.5539/ijef.v8n6p219

URL: http://dx.doi.org/10.5539/ijef.v8n6p219

\begin{abstract}
The purpose of the present study is to analyze the influence of economic factors on accounting profit transparency. Economic factors consist of economic growth, liquidity growth rate, annual deposit interest rate, currency, and inflation rate. In this research in order to determine profit transparency Barth et al. (2008) model has been implemented. This model defines transparency as the simultaneous change of profit and profit changes along with stocks feedback. The data are quantitative and at relative scale which depend on regression analysis and interpretation and Pearson correlation factor. To this end, research hypotheses have been tested by implementing apposite statistic methods by the use of SPSS software. Macroeconomic variables values have been collected from the data published by the central bank. The research population consists of basic metals industry companies listed on Tehran Stock Exchange during 2009-2014. The research findings show that there is a significant and positive relationship between macroeconomic variables under the present study and that of dependent variable of profit transparency.
\end{abstract}

Keywords: economic growth rate, liquidity growth rate, deposit interest rate, currency rate, inflation rate, profit transparency

\section{Introduction}

One of the most important reported financial data by every company is the company profit. In fact investors and many other financial users consider accounting profit as a significant data source which allows them to estimate the actual performance of the company and make decisions on the basis of that. Since accounting profit is a tool in the hand of management it is possible that in a number of cases accounting does not show a precise picture of the performance of the company and thanks to the use of judgments and related estimations require the provision of complementary data to enhance efficiency of the data. The circulation of cash and accruals can provide the users with complementary data in terms of economic performance and accounting profit and stock returns. By considering the importance of investors in stock markets the most important tools for providing the apposite facility to attract the presence of investors, understanding the sensitivity of profit and also the use of economic tools. Despite the presence of various limitations in terms of implementing economic tools we see that these tools are increasingly applied by the investors at Stock Exchange market. Therefore, precise understanding of macroeconomic variables and their usage can benefit the investors at economic decision makings. Study of the influence of economic factors on accounting profit transparency as a significant criterion for the accounting data users can considerably assist in terms of investors financial decision makings. Therefore, the significance of the presence study lies in the expansion and spread of economic data on accounting and financial data. Therefore, it facilitates the efficiency of decision making for different users such as investors, creditors, banks, and stock market. To this end, the present research tries to analyze the impact of economic growth rate, liquidity growth rate, deposit interest rate, currency rate, and inflation rate as one of the macroeconomic variables on companies' profit transparency.

\subsection{Statement of the Problem}

In macroeconomic theories one of the signs and factors of economic stability is the low rate of inflation. 
Therefore, most of the countries in developed countries and developing countries have a special look at inflation issue and by the application of various monetary and financial policies try to control it and stabilize the price. Inflation as one of the economic variables has a destructive impact on the state policy and economic structure and influences economic growth, revenue and wealth distribution, social and political conditions of the country. Over the last three decades the inflation in Iran has become double digits. Therefore, the double digit inflation is among the structural problems of the economy of Iran which has been influenced by the economic performance of Iran in the years after the imposed war against Iran by Iraq. Similarly, inflation can cause negative impacts on revenue distribution, consumption, distribution of resources, efficiency and state budget. Inflation has a significant impact on social economic conditions and the type of investment. At inflation situation it is evident that maintaining the power of purchasing is highly important and among the ways to do it is the investment in profitable activities such as stock trading can be referred to as an instance of investment.

By considering the impact of inflation on social economic condition and the type of people investment undoubtedly inflation influences stock exchange and every company. At inflation condition where the purchasing power of the people gets reduced the rise of life expense is so that there is no chance of making savings and the fall of saving leads to fall of investment and decline of the stock exchange activities and the fall of the stock market feedback.

On the one hand the financial analysts in their assessments need to consider not only the profit quantity but also the profit transparency. Profit transparency is a significant criterion to assess the financial health of the trade unit, a multi-dimensional concept with multiple aspects and no single meaning. Therefore, various definitions as well as different measurement scales in this respect has been presented but because of the complexity of the concept no single definition can be put forward. Companies in action in countries with high-risk of investment and low economic security compared with other companies have low levels of profit transparency. Therefore, in the analysis of the profit transparency factors such as economic and political issues such as the state interference, relations with other countries, and the rate of interactions, economic risk and security of investment need to be carefully considered (Namazi \& Rezaee, 2013).

\section{Review of the Literature}

Namazi and Rezaee (2013) in a research entitled the impact of inflation on profit quality of the listed companies in Tehran exchange market and that the inflation rate did not have any significant impact on non of the selected criteria of profit quality at the scale of all industries; but by the analysis of it at each industry it became clear that in a number of industries there was a significant relation between profit quality criteria and the rate of inflation. At auto industries and machinery, the inflation rate has a significant and positive relationship with profit stability at minerals and ores the inflation rate had a significant and negative relationship with honest reporting and in steel metal industries and other industries there was a negative and significant relationship between timely reporting. In addition to that no negative relationship was observed in terms of the relationship between profit predictive value and inflation rate in six industries under the study.

Rin Kupe and Anderson Bereka (2012) in a research entitled economic variables and profit stability of the listed companies in Brazil exchange market in order to reach the goals of their research analyzed 192 companies from 1995-2011(20 years) and by the use of Granger causality test showed that there is a negative and significant relationship between profit stability and inflation rate and interest rate.

Kim and gue (2010) studies profit quality and stock feedback with macroeconomic variables. They made use of accruals quality as a criterion to estimate profit quality and concluded that the quality of the accruals quality changes by macroeconomic variables. In fact companies with low accruals quality have low rate in proportion with economic shocks and evolutions are much more susceptible.

Karimi et al. (2015) in their research have analyzed the impact of economic and accounting variables on investment structure of the listed companies in Tehran stock exchange market. The obtained results confirms the accuracy of the research hypotheses which shows a positive impact of currency rate variables, the amount of bank credits, stock profit payment rate, the proportion of short-term debt and the proportion of long-term debt and the negative impact of the inflation rate, GDP and the impact of interest rate on the investment structure of the companies of listed companies in Tehran exchange market.

Hejazi et al. (2011) have studies the impact of economic growth variables and economic liberty and the lack of profit transparency in Tehran exchange market. They showed that the lack of profit transparency has a direct relationship with economic growth but there is not a significant relationship between lack of profit transparency and economic liberty. 
Bulu and Rahmani far (2014) in an analysis have studies the relationship between profit transparency and the expenses of the stock owners and the relationship between profit transparency and the irregular feedback. The results of the research showed that there is a negative and significant relationship between profit transparency and the expenses of the stock owners and similarly the results showed that there is a negative and significant relationship between profit transparency and irregular feedback. In other words the companies with more transparent profits will experience less irregular feedbacks.

Denilson et al. (2014) in their research analyzed the impact of accounting transparency, organizational complexity and investment expenses more than market liquidity of a company. Studies showed that as the rate of accounting profit transparency increased the rate of inclination rate to investment in that company and also concluded that the managers of the companies are inclined with extra investment in terms of accounting profit transparency to increase foreign investment in their companies. The managers of the companies with this managerial strategy such investments are a forward movement towards the front to attract investment.

Mahmud et al. (2011) in a research have analyzed the impact of macroeconomic variables on the capital structure in there countries of Japan, Malaysia and Pakistan. They showed that economic factors and variables have significant role in determining companies' capital structure that in inapposite economic conditions can create limitations for companies in terms of financial provision.

Sung Shin and Adrin (2009) in a research have studied the relationship between interest rate, the rate of GDP, inflation and currency rate with capital structure in a sample of Germany, France, Italy, England for a 20 year period. They reported in their conclusion that apposite or inapposite economic conditions of the corresponding country influences the rate of companies' capital structure and to determine an optimal capital structure not only the internal factors of the company are influential but also the economic condition related to the macroeconomic fluctuations and the policies made in relation to them need to be considered.

\section{Research Hypotheses}

\subsection{Main Research Hypothesis}

There is a significant relationship between macroeconomic variables and accounting profit transparency

\subsection{Secondary Hypotheses}

1). There is a significant relationship between economic growth and accounting profit transparency

2). There is a significant relationship between liquidity and accounting profit transparency

3). There is a significant relationship between annual investment deposits and accounting profit transparency

4). There is a significant relationship between accounting profit transparency and currency rate

5). There is a significant relationship between accounting profit transparency and inflation rate

\section{Research Population and Sample}

The research population consists of companies listed on Tehran Stock Exchange with the following features:

1)- The company is not a member of investment companies and financially mediating and the insurance companies. This is because of different operational identity of the aforementioned companies.

2)- Their capitals consist of normal capitals and do not have preferred stock. That is because of the twofold quality of the preferred stock that one the one hand because of promising the interest rate has the quality of debt and on the other hand has the quality of trading and the companies listed on Tehran Stock Exchange lack this quality.

3)- The financial year of the company ends up in March. This is because of providing integrity among companies in terms of the seasonal changes in the performance of the companies.

4)- The company stock has been traded from the beginning of 2009 until 2014 in companies listed on Tehran Stock Exchange.

In the present study the research population consists of all companies listed on Tehran Stock Exchange 444 that by the analysis of financial statements and the imposition of limitations aforementioned and incidental sampling finally 44 companies had the required conditions to be extracted.

\section{Methodology}

The present study is a deductive and descriptive research type and correlation and post-event research (by the use of past data) which is sectional the data is quantitative and at relative scale which is based on analysis and 
interpretation of regression and Pearson correlation coefficient. In the present research in order to determine the rate of dependent variable explanation by the independent variable from the $\mathrm{R}^{2}$ adjusted has been implemented. In the present study in order to define the profit transparency Barth model et al (2008) has been implemented. This model introduces transparency as the simultaneous profit change and profit change with stock feedback. The $\mathrm{R}$-squared is $\left(\mathrm{R}^{2}\right)$ which is obtained from the stock feedback regression against profit and its changes. This index is interpreted as the profit transparency because the profit and the change of profitability show the changes of the economic conditions which be the economic changes of the company have been estimated by the stock feedback. To estimate the transparency the following model has been planned:

$$
R_{i, t}=a_{0}+a_{1} E_{i, t} / P_{i, t-1}+a_{2} \Delta E_{i, t} / P_{i, t-1}+\varepsilon_{i, t}
$$

To estimate the annual company stock the following relation has been used:

$$
R_{i, t}=\frac{P_{t}(1+\alpha+\beta)-\left(P_{t-1}+C \alpha\right)+D_{t}}{P_{t-1}+C \alpha}
$$

Multi-variable regression model would also be analyzed to estimate the influence of all independent variables at the same time on the dependent variable. To this end, multiple regression model of estimating the relation between accounting profit transparency and economic variables:

$$
A P T_{i t}=\alpha+\beta_{I}(E G)_{i t}+\beta_{2}(L G)_{i t}+\beta_{3}(A R)_{i t}+\beta_{4}(C R)_{i t}+\beta_{5}(I R)_{i t}+\varepsilon
$$

In which:

\begin{tabular}{|c|c|c|}
\hline Estimation method & Explanation & Type of the variable \\
\hline Barth et al model: & Accounting profit & Dependent \\
\hline$R_{i, t}=a_{0}+a_{1} E_{i, t} / P_{i, t-1}+a_{2} \Delta E_{i, t} / P_{i, t-1}+\varepsilon_{i, t}$ & transparency & \\
\hline Calculated by the annual GDP growth. The value is announced by the central bank & Economic growth & Independent \\
\hline $\begin{array}{c}\text { Calculated by dividing the legal savings of the banks. The value is announced by the } \\
\text { central bank. }\end{array}$ & Liquidity growth & Independent \\
\hline Determined and ordered by the central bank & Investment interest rate & Independent \\
\hline According to American dollar rate & Currency rate & Independent \\
\hline Announced by the central bank at different periods & Inflation rate & Independent \\
\hline
\end{tabular}

$$
\begin{aligned}
& \mathrm{APT}_{\mathrm{it}}=\text { Accounting Profit Transparency } \\
& \mathrm{EG}_{\mathrm{it}}=\text { Economic Growth } \\
& \mathrm{LG}_{\mathrm{it}}=\text { Liquidity Growth } \\
& \mathrm{AR}_{\mathrm{it}}=\text { Annual Rate } \\
& \mathrm{CR}_{\mathrm{it}}=\text { Currency Rtae } \\
& \mathrm{IR}_{\mathrm{it}}=\text { Inflation Rate }
\end{aligned}
$$

Variables and the method of estimating the variables of the present study in a tabular format as follows:

\section{Research Hypotheses Test Results and Analysis}

\subsection{First Hypothesis Test Results}

First Hypothesis states that there is a significant relationship between economic growth rate and profit transparency:

\begin{tabular}{cccccc}
\hline \multicolumn{6}{c}{ Model summary table } \\
\hline Model & Correlation coefficient & R-squared & $\mathrm{R}^{2}$ adjusted & Standard error deviation & Durbin Watson \\
\hline 1 & $.188 \mathrm{a}$ & .035 & .032 & 61.4238815 & 1.134 \\
\hline
\end{tabular}

Independent variable: economic growth rate.

Dependent variable: profit transparency.

Since the correlation coefficient between management efficiency independent variable of the current year and the dependent Spring Gate index of the coming year equals $-0 / 188$ and the value of probability concerning its 
significance $H_{0}: \rho=0$ equals $0 / 001$ which is smaller than $0 / 05$ then the $\mathrm{H} 0$ is not approved. Therefore, with $95 \%$ certainty the existence of positive and significant relation between them is approved. And also by considering the fact that $\mathrm{R}^{2}$ adjusted model ( $\mathrm{r} 2$ ) equals $0 / 032$ so that around $3.2 \%$ of the response variable changes (profit transparency) by the independent variable (economic growth rate) can e described as could be expected by the rise of economy in a country the environment of the competing companies expand. Rise of competition increase the chances of elimination from the competition scene and this can decrease the profit of the company and devalue the attempts made by the high ranking management (Smith 1997, Hermlin, 1992, Skarf stein 1988). It was predicted that along with the rise of economy the accounting profit transparency rate get debased and the high ranking managers commit cheating to remain in the market and the research findings do not support this prediction.

\subsection{The Results of the Second Hypothesis Test}

The second hypothesis states that there is a significant relationship between liquidity growth rate and profit transparency:

\begin{tabular}{cccccc}
\hline \multicolumn{5}{c}{ Model summary table } \\
\hline Model & Correlation coefficient & R-squared & R2 adjusted & Standard error deviation & Durbin Watson \\
\hline 1 & $.845^{\text {a }}$ & .713 & .712 & 33.489917 & 1.148 \\
\hline
\end{tabular}

Independent variable: liquidity growth rate.

Dependent variable: profit transparency.

By considering the fact that correlation coefficient between management efficiency independent variable of the current year and the dependent Spring Gate index of the coming year equals $0 / 845$ and the value of probability concerning its significance $H_{0}: \rho=0$ equals $0 / 000$. And also by considering the fact that $\mathrm{R}^{2}$ adjusted model ( $\left.\mathrm{r} 2\right)$ equals $0 / 712$ so that around $71 / 2 \%$ of the response variable changes (profit transparency) by the independent variable (liquidity growth rate) can e described the value of the null hypothesis based on lack of linear relation between independent variable and the response variable (H0) equals $0 / 000$ which is smaller than 0/05 and therefore, with $95 \%$ certainty this statistical hypothesis is not approved, an as a result a significant linear relation between two variables can be observed and thereby second hypothesis (H1) is approved.

\subsection{Results of the Third Hypothesis}

Third hypothesis states that there is a significant relation between annual deposit interest rate with profit transparency:

\begin{tabular}{rccccc}
\hline \multicolumn{5}{c}{ Model summary table } \\
\hline Model & Correlation coefficient & R-squared & $\mathrm{R}^{2}$ adjusted & Standard error deviation & Durbin Watson \\
\hline 1 & $.202^{\mathrm{a}}$ & .041 & .038 & 61.248876 & 1.239 \\
\hline
\end{tabular}

Independent variable: annual deposit interest rate.

Dependent variable: profit transparency.

By considering the fact that correlation coefficient between management efficiency independent variable of the current year and the dependent Spring Gate index of the coming year equals $0 / 845$ and the value of probability concerning its significance $H_{0}: \rho=0$ equals $0 / 000$. And also by considering the fact that $\mathrm{R}^{2}$ adjusted model (r2) equals $0 / 038$ so that around $3.8 \%$ of the response variable changes (profit transparency) by the independent variable (annual deposit interest rate) can e described the value of the null hypothesis based on lack of linear relation between independent variable and the response variable (H0) equals $0 / 000$ which is smaller than 0/05 and therefore, with $95 \%$ certainty this statistical hypothesis $\mathrm{H} 0$ is not approved, an as a result a significant linear relation between two variables can be observed and thereby second hypothesis (H1) is approved.

\subsection{Results of the Fourth Hypothesis}

Fourth hypothesis states that there is a significant relation between currency rate with profit transparency: 


\begin{tabular}{cccccc}
\hline \multicolumn{5}{c}{ Model summary table } \\
\hline Model & Correlation coefficient & R-squared & $\mathrm{R}^{2}$ adjusted & Standard error deviation & Durbin Watson \\
\hline 1 & $.823^{\mathrm{a}}$ & .678 & .677 & 35.492033 & 1.042 \\
\hline
\end{tabular}

Independent variable: currency rate.

Dependent variable: profit transparency.

By considering the fact that correlation coefficient between management efficiency independent variable of the current year and the dependent Spring Gate index of the coming year equals 0/823 and the value of probability concerning its significance $H_{0}: \rho=0$ equals $0 / 000$. And also by considering the fact that $\mathrm{R}^{2}$ adjusted model (r2) equals $0 / 677$ so that around $67.7 \%$ of the response variable changes (profit transparency) by the independent variable (currency rate) can e described the value of the null hypothesis based on lack of linear relation between independent variable and the response variable (H0) equals 0/000 which is smaller than 0/05 and therefore, with 95\% certainty this statistical hypothesis $\mathrm{HO}$ is not approved, an as a result a significant linear relation between two variables can be observed and thereby second hypothesis (H1) is approved. It was predicted that according to the currency fluctuations and differences at currency rate increase report be influenced in the financial statement of accounting profit transparency value and decrease by the rise of accounting profit transparency rate that on the basis of obtained results this hypothesis confirmed.

\subsection{Results of the Fifth Hypothesis}

Fifth hypothesis states that there is a significant relation between inflation rate with profit transparency:

\begin{tabular}{cccccc}
\hline \multicolumn{5}{c}{ Model summary table } \\
\hline Model & Correlation coefficient & R-squared & $\mathrm{R}^{2}$ adjusted & Standard error deviation & Durbin Watson \\
\hline $\mathbf{1}$ & $.228^{\mathrm{a}}$ & .052 & .049 & 60.893327 & 1.236 \\
\hline
\end{tabular}

Independent variable: inflation rate.

Dependent variable: profit transparency.

By considering the fact that correlation coefficient between management efficiency independent variable of the current year and the dependent Spring Gate index of the coming year equals 0/228 and the value of probability concerning its significance $H_{0}: \rho=0$ equals $0 / 000$. And also by considering the fact that $\mathrm{R}^{2}$ adjusted model (r2) equals $0 / 049$ so that around $4.9 \%$ of the response variable changes (profit transparency) by the independent variable (inflation rate) can be described the value of the null hypothesis based on lack of linear relation between independent variable and the response variable (H0) equals 0/000 which is smaller than 0/05 and therefore, with 95\% certainty this statistical hypothesis $\mathrm{HO}$ is not approved, an as a result a significant linear relation between two variables can be observed and thereby second hypothesis (H1) is approved. It was predicted that according to the currency fluctuations and differences at currency rate increase report be influenced in the financial statement of accounting profit transparency value and decrease by the rise of accounting profit transparency rate that on the basis of obtained results this hypothesis confirmed.

\subsection{Summary of the Hypotheses Test Results}

In the present research five hypotheses were presented and after their analyses it became evident that there is a significant and positive between the macroeconomic variables of the present study namely economic growth rate, liquidity growth rate, annual deposit interest rate and inflation rate and currency rate with dependent variable of accounting profit transparency by $95 \%$ probability which was approved.

\section{References}

Andrade, C. S., Bernile, G., \& Hood, M. F. (2009). SOX, Corporate Transparency, and the Cost of Debt. Journal of Financial Intermediation, 18(4), 541-558. http://dx.doi.org/10.2139/ssrn.1257002

Azar, A., \& Mansur, M. (2003). Statistics and its application in management (statistical analysis). Tehran SAMT.

Bartley, D., David, H., Robert, V. N., \& Richard, W. (2014). Liquidity, Accounting Transparency, and teh Cost of Capital: Evidence from Real Estate Invetment Trusts. Journal of Real Estate Research, 36(2), 221-251.

Bulu, G., \& Rahmani, M. M. (2014). The cost of stock holders and profit transparency. Experimental Researches of Accounting, (8), 59-80. 
Dongcheol, K., \& Yaxuan, Q. (2010). Accruals Quality, Stock Returns, and Macroeconomic Conditions. The Accounting Review, 85(3), 937-978. http://dx.doi.org/10.2308/accr.2010.85.3.937

Hejazi et al. (2011). The impact of economic variables and economic liberty on the profit transparency. Financial Accounting Studies, (5), 1-16

Karimi, F., Forughi, D., Noruzi, M., \& Madine, S. H. (2015). Study of the economic variables and accounting on the listed companies in Tehran exchange market financial structure.

Muhammad, M., Herani, G. M., Rajar, A. W., \& Farooqi, W. (2011). Economic factors influencing corporate capital structure in three Asian countries: Evidence from Japan, Malaysia and Pakistan. Journal of Management and Social Sciences, 3(1), 9-17.

Namazi, M., \& Hamid, R. R. (2013). The impact of inflation rate on profit quality of the listed companies at Tehran exchange market. Accounting Experimental Researches, 31-67.

Renê, C. P., \& Andson, B. A. (2012). Economic Variables and Earnings Persistence in Brazil. Springer Science+Business Media New York 2012.

Song, S. H., \& Adrian, T. (2009). Federal Reserve Bank of New York staff reports. Accounting Review, 12, 305-334.

\section{Copyrights}

Copyright for this article is retained by the author(s), with first publication rights granted to the journal.

This is an open-access article distributed under the terms and conditions of the Creative Commons Attribution license (http://creativecommons.org/licenses/by/3.0/). 